\title{
Demand Forecasting of Toyota Avanza Cars in Indonesia: Grey Systems Approach
}

\author{
Fitrah Amalia Arsy ${ }^{1, *}$ \\ ${ }^{1}$ School of Business, Nanjing University of Information Science and Technology, Nanjing, China \\ *Corresponding author: fitrahamaliaarsy@gmail.com
}

Received 26 June 2021; Revised 14 July 2021; Accepted 14 July 2021

\begin{abstract}
Toyota Avanza car is a popular four-wheeler among Indonesia middle-class customers. The current study aims to forecast the demand for Toyota Avanza cars in Indonesia in the next six years using the grey forecasting model EGM $(1,1, \alpha, \theta)$. The comparative analysis of the results obtained from the grey model with those of Linear Regression, Exponential Regression, and Exponential Triple Smoothing techniques revealed the superiority of the grey model as it produced most accurate forecasts. The accuracy was measured through the Mean Absolute Percentage Error. The results revealed, the car sales are likely to decline in the future. Although forecasts are never completely accurate, forecasting can provide a reference for developing strategy to meet future demand. The results are important for Toyota Avanza car manufacturers in Indonesia.
\end{abstract}

Keywords: Sales forecast; Toyota Avanza; automobile demand; Indonesia; grey forecasting

\section{Introduction}

In early 2017, Toyota had controlled nearly 40\% of Indonesia's total market share of four-wheeled vehicles. That means 4 out of 10 new cars sold in Indonesia each year are Toyota (Chalil, 2017: 5). Who is the person in Indonesia who does not know the Toyota Avanza? Many Indonesian families choose this car and almost always dominate sales in the Low Multi-Purpose Vehicle (LMPV) class. The Avanza was first introduced at the 2003 Gaikindo Auto Show to enter the Indonesian market as a new choice as a family car for Indonesians (Rio, 2019). Avanza in the Indonesian MPV market continues to show its success. Even now, the Toyota Avanza is the most MPV category passenger vehicle on Indonesian roads. Sales data from the Association of Indonesian Automotive Industries (Gaikindo) also shows the MPV of the Avanza brand number one every month (DetikOto, 2010). Many factors cause the market for the Toyota Avanza to fluctuate, which has a wide and varied market share, ranging from low prices to stylish ones at higher prices (Soerjopranoto, 2017).

On the other hand, people consider several things when buying a product. The consideration is according to the needs or based on his wishes. Price is also another consideration. Toyota Avanza is a car that families love in Indonesia with all its capabilities and a relatively affordable price. There were no rivals at that time when he walked alone for years, becoming an idol and market leader in Indonesia at the beginning of its launch in 2003, and from there, the Toyota Avanza continues to plant the image of a million cars. The Toyota Avanza has been working for 17 years in Indonesia to become the bestselling low multipurpose vehicle (LMPV) in Indonesia.

Even though the Toyota Avanza is the best-selling car for dozens of years in Indonesia, now the car had to experience a decline in sales due to the outbreak of the COVID-19 pandemic, which has 
weakened the Indonesian currency. When sales were sluggish due to this outbreak, the price of Toyota Avanza cars went up. Marketing Director of PT Toyota Astra Motor has confirmed this price hike (Jimmi, 2020). The production cost factor and the rupiah exchange rate against the US dollar are the reasons for the increase in car prices. His side has also thought about this price increase so as not to cause demand to decrease drastically. However, he did estimate that there would be an impact on the sales figures from increased car prices. Events that occur in the next six years, from 2020 to 2025, will greatly affect sales, which have fluctuated compared to sales in the last few years. Thus, there is a dire need to have accurate forecasts of the demand for these cars.

PT Toyota- Astra Motor (TAM) and PT Toyota Motor Manufacturing Indonesia (TMMI) are key stakeholders in the Toyota market. TMMIN focuses as a vehicle manufacturing company and vehicle components as well as an exporter of the whole, semi-finished vehicles, vehicle components including engines and production aids. Meanwhile, TAM focuses as a distributor of Toyota branded vehicles and after-sales service. In Indonesia, Toyota is represented by two subsidiaries, namely PT Toyota Motor Manufacturing Indonesia (TMMIN) and PT Toyota Astra Motor (TAM). As a subsidiary of Toyota Motor Corporation headquartered in Japan, TMMIN acts as a manufacturer and exporter of Toyota products and parts, while TAM acts as an agent brand holder, importer and distributor of Toyota products. PT Toyota Motor Manufacturing Indonesia (TMMIN) for more than four decades, TMMIN has played an important role in developing the automotive industry in Indonesia and job opportunities for its supporting industries. Currently, TMMIN has five factories operating in Sunter and Karawang, Indonesia (PT, 2014). Data from these stakeholders can be a rich resource for forecasting demand for Toyota vehicles.

From Figure 1 (data from Gaikindo), it is clear that a continuous decline occurred every year starting from 2013 with 213,458 units until it decreased in 2018 with total sales of 82,167 units. However, in 2019 the number of sales increased by 4,207, making sales in 2019 to 86,374 units. Although the Toyota Avanza continued to decline in 2019 could be a good sign for the company because of an increase. Executive General Manager of TAM, Fransiscus Soerjopranoto, said that many things affect sales figures' ups and downs (wholesale and retail sales). "Basically, the ups and downs of the wholesale or retail sales figure are influenced by many things, both the market condition itself and the availability of units at the dealer"(Budiman, 2018). Therefore, forecatsing accurate demand for the Toyota Avanza is important for the industry.

The rest of the study is organized as follows. Section two presents the review of the literature. Section three is about research methodology. Section four presents the results and discussion. Section five concludes the study.

\section{Literature Review}

\subsection{Toyota Avanza Cars in Indonesia}

For the upper-middle class in Indonesia, a car is a means of personal transportation needed to carry out their daily activities. Cars are used to go to work, school, market, meet relatives, on vacation, or even transport goods. Cars help speed up daily activities, although some people buy cars to increase their prestige in society, and not as a matter of necessity (Riyanto, 2005). In Indonesia, the total number of motorized vehicles has touched hundreds of millions of units, reaching 146,858,759 units. Most of them are dominated by motorbikes with more than 100 million units, namely 120,101,047 units and 16,440,987 units cars, according to data from the Central Statistics Agency (BPS) in 2018. According to data from the Association of Indonesian Automotive Industries (Gaikindo), in 2019, Indonesia has paved 1,043,017 new cars. That figure is retail sales (from dealers to consumers), including sales of commercial vehicles such as trucks and buses (Rahardiansyah, 2020).

At the end of 2003, the Indonesian marketing world was shocked by Toyota's latest product, when the Toyota Avanza brand was launched (Hermawan, 2004). Since it was first introduced to the public in December 2003, the Toyota Avanza was immediately greeted with great enthusiasm by the Indonesian people, where more than 43,000 Avanza units were sold in its inaugural year. With a reliable and robust DNA 7-Seater Multipurpose Vehicle (MPV), at the age of 16, Avanza is increasingly trusted by the public to become the best-selling MPV in Indonesia with more than 1.8 million subscribers. In 2019, Avanza sales figures grew by $6.9 \%$ compared to the previous year, amidst a decline in market 


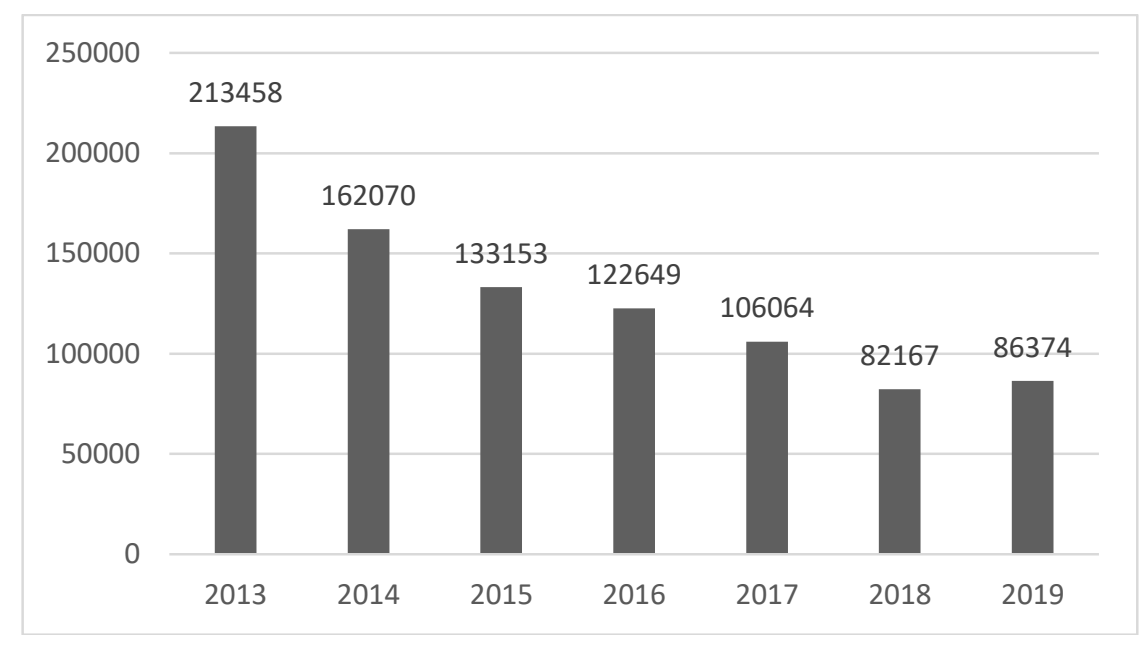

Figure 1. Toyota Avanza car sales from 2013 to 2019

demand of $11.1 \%$ in the Low MPV segment. This data proves that Avanza remains an option because it can meet the expectations and needs of the Indonesian (Sikker, 2019).

It seems that the Toyota Avanza is not only in demand by Indonesians. Many people in other countries are also quite interested in this million people's MPV car. The tastes and choices of the neighbouring countries such as the Philippines, Myanmar, Vietnam, Thailand, Brunei Darussalam, Laos, Singapore and Malaysia are comparable to those of Indonesia. That is why these ASEAN countries are listed in the Avanza export data. Not to forget that outside of ASEAN, there are South Africa, Bermuda, West Africa, Madagascar, Pakistan, Srilanka, Saudi Arabia, Peru, Bangladesh, Lebanon, Qatar, Kuwait, Oman, Yemen, Honduras, Guatemala, and several other countries that also import Toyota Avanza (Rayanti, 2018).

The Toyota brand still dominates the top five Indonesian assembled cars that sell overseas. The Indonesian Automotive Industry Association's databases (Gaikindo) confirm this fact. Avanza sits in second place under the big Toyota Fortuner. From January to November 2018, 32,536 Toyota Avanza units were sent from Indonesia to overseas (Rayanti, 2018). From this data, it can be seen that the Toyota Avanza is not only popular and well-known in Indonesia, but also to various countries around the world who are interested in this car.

\subsection{Demand Forecasting of Automobiles in Indonesia}

Demand theory explains the habitude of buyer demand for a commodity (goods and services) and explains the relationship between the number demanded and the price and the formation of the demand curve (Sugiarto et al., 2007). Demand is the various quantities of goods demanded by consumers at various price levels in a certain period (Pracoyo \& Pracoyo, 2006: 29). Many factors influence consumer demand for an item, including price, income, taste, season, population, etc. Thus, it can be concluded that demand is the desire of buyers or consumers accompanied by the availability of goods and buyers' ability to buy goods or services at a specific price and time.

Forecasting is an attempt to predict future conditions through testing conditions in the past. The essence of forecasting is predicting future events based on past patterns; and using policies on projections with past patterns. Simply put, forecasting is the art and science of predicting future events. This can be done by involving past data collection and placing it into the future with a mathematical model (Prasetya \& Lukiastuti, 2009). Demand forecasting is the projection of demand for a company's products or services that control production, capacity and scheduling systems and become input for financial planning, marketing and human resources (Prasetya \& Lukiastuti, 2009). This prediction predicts the demand for cars by the Toyota Avanza Cars company in Indonesia at each time horizon by using time series data for sales of Toyota Avanza Cars in Indonesia from 2013-2019.

Trend analysis makes a general trend model for time series data and allows forecast calculations for future data periods. Several models are commonly used for trend analysis: the linear trend model, the quadratic trend model, the exponential growth trend model, and the S-Curve model (Rusli, 2014). In this study, the type of trend used is the Linear Trend model, or it can be called the linear least square 
Table 1. Summary of literature on automobile forecasts

\begin{tabular}{|c|c|c|c|c|c|}
\hline Year & $\begin{array}{l}\text { Region } \\
\text { of focus }\end{array}$ & $\begin{array}{c}\text { Automobile } \\
\text { type }\end{array}$ & Description & Model & Literature \\
\hline 1981 & Japan & $\begin{array}{l}\text { All automobile } \\
\text { type }\end{array}$ & $\begin{array}{l}\text { The study outlines the use of } \\
\text { linear and nonlinear models in } \\
\text { forecasting net car sales of the } \\
\text { Japanese automotive industry. }\end{array}$ & $\begin{array}{l}\text { Linear and } \\
\text { nonlinear models } \\
\text { and GMDH } \\
\text { method. }\end{array}$ & $\begin{array}{l}\text { Nishikawa and } \\
\text { Shimizu (1981) }\end{array}$ \\
\hline 1985 & USA & $\begin{array}{l}\text { All automobile } \\
\text { type }\end{array}$ & $\begin{array}{l}\text { Describes a simulation model } \\
\text { for the U.S. automobile } \\
\text { market. }\end{array}$ & $\begin{array}{l}\text { Disaggregate } \\
\text { Choice models. }\end{array}$ & Berkovec (1985) \\
\hline 1997 & Spain & $\begin{array}{l}\text { All automobile } \\
\text { type }\end{array}$ & $\begin{array}{l}\text { The study investigates the } \\
\text { forecasting ability of } \\
\text { unobserved component } \\
\text { models. }\end{array}$ & ARIMA models. & Ferrer et al. (1997) \\
\hline 2009 & USA & $\begin{array}{l}\text { All Automobile } \\
\text { Type } \\
\text { (Domestics and } \\
\text { International) }\end{array}$ & $\begin{array}{l}\text { The study forecasted the } \\
\text { automobile sales using the } \\
\text { SPSS statistical package. }\end{array}$ & $\begin{array}{l}\text { Regression } \\
\text { models. }\end{array}$ & $\begin{array}{l}\text { Shahabuddin } \\
\text { (2009) }\end{array}$ \\
\hline 2010 & Palestine & $\begin{array}{l}\text { All automobile } \\
\text { type }\end{array}$ & $\begin{array}{l}\text { The study forecasted } \\
\text { automobile demand for the } \\
\text { economies in transition. }\end{array}$ & $\begin{array}{l}\text { Simultaneous- } \\
\text { equation model. }\end{array}$ & $\begin{array}{l}\text { Abu-Eisheh and } \\
\text { Mannering (2010) }\end{array}$ \\
\hline 2012 & $\begin{array}{l}\text { Solo, } \\
\text { Indonesia }\end{array}$ & $\begin{array}{l}\text { Mitshubisi Colt } \\
\text { T120 }\end{array}$ & $\begin{array}{l}\text { To see the demand forecast for } \\
\text { Mitsubishi Colt T120 cars at } \\
\text { PT Sun Star Solo in April } 2012 .\end{array}$ & $\begin{array}{l}\text { Single Moving } \\
\text { Average, Weight } \\
\text { Moving Average, } \\
\text { and Exponential } \\
\text { Smoothing. }\end{array}$ & Putri (2012) \\
\hline 2018 & Indonesia & $\begin{array}{l}\text { Mitshubisi } \\
\text { Xpander }\end{array}$ & $\begin{array}{l}\text { To forecast the demand of the } \\
\text { automobile. }\end{array}$ & $\begin{array}{l}\text { Moving Average, } \\
\text { Exponential } \\
\text { Smoothing and } \\
\text { Trend Analysis. }\end{array}$ & Iwan et al. (2018) \\
\hline 2020 & Japan & $\begin{array}{l}\text { Sedans and } \\
\text { Commercial } \\
\text { Cars }\end{array}$ & $\begin{array}{l}\text { The study focused on } \\
\text { automobile demand } \\
\text { forecasting. Two models were } \\
\text { built to predict the demand of } \\
\text { two classes of cars in Japan } \\
\text { every month for up to } 36 \\
\text { months in advance. }\end{array}$ & FMC and MMC. & Kato (2020) \\
\hline 2021 & Indonesia & Toyota Avanza & $\begin{array}{l}\text { To forecast the demand (sales) } \\
\text { of Toyota Avanza in } \\
\text { Indonesia. }\end{array}$ & $\begin{array}{l}\text { Grey Forecasting } \\
\text { model EGM } \\
(1,1, \alpha, \theta) .\end{array}$ & The current study \\
\hline
\end{tabular}

trend because it is very suitable and easily understood by researchers. The linear trend is a long-term, slow movement and tends to go in one direction, towards an up or down direction (Rusli, 2014). Table 1 summarizes the literature on forecasting of automobiles.

\section{Research Methodology}

\subsection{Data Collection}

In this study, the type of forecasting used is demand forecasting using secondary data. Secondary data is a historical data structure regarding the variables that have been previously collected and compiled by other parties (Hermawan, 2005). The data was collected from Gaikindo (www.gaikindo.or.id/indonesian-automobile-industry-data) from the 2013 - 2019 period. It contains sales data from PT Toyota-Astra Motor (TAM) and PT Toyota Motor Manufacturing Indonesia (TMMI).

\subsection{Forecasting techniques}

The study used a Grey Forecasting model, and then comparative analysis with three popular statistical models was performed using the Mean Absolute Percentage Error.

3.2.1 Even Grey Model $(1,1, \alpha, \theta)$. Grey system theory is a scientific theory first put forward by the Chinese scientist Julong Deng in the 1980s (Aydemir, 2020), and one of the strengths of this theory and its grey forecasting models is the ability to perform well using small samples and information, which 
can be incomplete (Javed et al., 2020a; Mahmoudi et al., 2020). Furthermore, the grey forecasting model is an intelligent time series prediction technique that can reliably forecast future patterns. Grey forecast allows you to get useful information about the future from small data, which can be up to four and can be used for short and long-term forecasts (Javed et al., 2020b). The term GM(1,1) indicates one variable and first-order differential (Lin et al., 2011). Even Grey Model $(1,1, \alpha, \theta)$ is a reliable forecasting model proposed by Javed et al. (2020c). Let the sequence of actual data is $X^{(0)}=\left(x^{(0)}(1), x^{(0)}(2), \ldots x^{(0)}(n)\right)$. And the sequence of conformable fractional accumulated data of $X^{(0)}$ is $X^{(\alpha)}=$ $\left(x^{(\alpha)}(1), x^{(\alpha)}(2), \ldots x^{(\alpha)}(n)\right)$ where, $x^{(\alpha)}(k)=\sum_{i=1}^{k}\left(\frac{x^{(0)}(i)}{i^{1-\alpha}}\right), k=1,2, \ldots, n$, where $\alpha$ values lie between 0 and 1 .

The time response equation of the model is given by,

$$
\begin{gathered}
\hat{x}^{(0)}(k)=k^{1-\alpha}\left(\hat{x}^{(a)}(k)-\hat{x}^{(a)}(k-1)\right), k=1,2, \ldots, n \\
\hat{x}^{(0)}(k)=k^{1-\alpha}\left(1-e^{\alpha}\right)\left(x^{(0)}(1)-\frac{b}{a}\right) e^{-a(k-1)}, k=1,2, \ldots, n
\end{gathered}
$$

The parameters a and b can be calculated through the least-squares method, such as

$$
[a, b]^{T}=\left[B^{T} B\right]^{-1} B^{T} Y
$$

where, $B=\left[\begin{array}{cc}-Z^{(1)}(2) & 1 \\ -Z^{(1)}(3) & 1 \\ \vdots & \vdots \\ -Z^{(1)}(n) & 1\end{array}\right]$ and $Y=\left[\begin{array}{c}x^{(0)}(2) \\ x^{(0)}(3) \\ \vdots \\ x^{(0)}(n)\end{array}\right]$

The complete details about the model and its parameters can be found in Javed et al. (2020c).

3.2.2 Linear Regression. The phenomenon of regression analysis aims to determine the regularity of phenomena development (Rusov et al., 2017). Based on this regularity, regression analysis can predict the future direction of phenomena. Regression models imply a class of stochastic models represented by equations in which the dependent variable is expressed as a linear or non-linear function of the independent variable (Flood, 2020). A linear regression model defines the relationship between the dependent and independent variables in a straight line. The Linear Regression formula is as follows:

$$
Y=a+b X
$$

In this formula, $\mathrm{a}$ is the value of $Y$ when $X$ is equal to 0 . The slope of the regression line is $\mathrm{b}$, which indicates the change in $Y$ for each unit of change in $X$. The current study used the following formula for demand forecasting in MS Excel,

$$
Y=-23856 * \text { year }+220091
$$

3.2.3 Exponential Regression. A non-linear regression method is a form of relationship or function in which the independent variable $X$ and/or the dependent variable $Y$ can function as a factor or variable with a certain rank. Besides, the independent variable $X$ and/or the dependent variable $Y$ can function as a denominator (fractional function), and the variable $X$ and/or the variable $Y$ can function as a power exponential function $=$ power function. One of the models of non-linear regression is exponential regression, where the independent variable $X$ functions as power or exponent. The form of this regression function is (Wahyudi, 2017):

$$
Y=a e^{b X}
$$

The current study used the following formula for demand forecasting in MS Excel:

$$
Y=240713^{*} \operatorname{EXP}\left(-0.175^{*} \text { year }\right) \text {. }
$$

3.2.4 Exponential Triple Smoothing. Calculates or predicts a future value based on existing (historical) values using the AAA version of the Exponential Smoothing (ETS) algorithm. The function of ETS is to estimate or calculate the future value based on the existing value. The estimated value is the continuation of the specified target date's historical value, which should be continued from the timeline. 
Table 2. Forecasting The Demand of Toyota Avanza Cars in Indonesia

\begin{tabular}{|c|c|c|c|c|c|c|c|c|c|}
\hline Year & Sales & $\begin{array}{c}\text { Linear } \\
\text { Regression }\end{array}$ & $\begin{array}{c}\text { Exponential } \\
\text { Regression }\end{array}$ & ETS & $\begin{array}{c}\text { EGM } \\
(1,1, \alpha, \theta)\end{array}$ & RGR & $\begin{array}{l}\text { Mean } \\
\text { RGR }\end{array}$ & $D_{t}$ & $\begin{array}{c}\text { Mean } \\
\mathbf{D}_{\mathrm{t}}\end{array}$ \\
\hline 2013 & 213458 & 196235 & 202068 & 192461 & 213458 & & & & \\
\hline 2014 & 162070 & 172379 & 169628 & 170426 & 162070 & 1.76 & \multirow{5}{*}{1.13} & 0.13 & \multirow{5}{*}{0.88} \\
\hline 2015 & 133153 & 148523 & 142395 & 148392 & 141177 & 1.35 & & 0.39 & \\
\hline 2016 & 122649 & 124667 & 119535 & 126357 & 122977 & 1.24 & & 0.48 & \\
\hline 2017 & 106064 & 100811 & 100344 & 104323 & 107123 & 1.17 & & 0.54 & \\
\hline 2018 & 82167 & 76955 & 84235 & 82288 & 93313 & 0.11 & & 2.89 & \\
\hline 2019 & 86374 & 53099 & 70711 & 60254 & 81284 & & & & \\
\hline 2020 & & 29243 & 59359 & 38219 & 70805 & 1.87 & \multirow{6}{*}{1.32} & 0.07 & \multirow{6}{*}{0.43} \\
\hline 2021 & & 5387 & 49829 & 16185 & 61677 & 1.41 & & 0.35 & \\
\hline 2022 & & -18469 & 41830 & -5850 & 53726 & 1.25 & & 0.47 & \\
\hline 2023 & & -42325 & 35114 & -27884 & 46800 & 1.17 & & 0.53 & \\
\hline 2024 & & -66181 & 29477 & -49919 & 40766 & 1.13 & & 0.57 & \\
\hline 2025 & & 220091 & 240713 & -71953 & 35511 & 1.1 & & 0.6 & \\
\hline
\end{tabular}

This ETS can be used to predict future forecasts, and the function can be used to predict future sales, inventory requirements, or consumer trends. In the current study, the ETS model was executed in MS Excel using its built-in function.

\subsection{Forecast Accuracy Measurement}

The performance of forecasting models is very important to be evaluated as a validation stage for models that are suitable for research data (Hakimah et al. 2020). The performance of the forecasting models in this study is based on the forecast errors generated by each model. The forecast error will be calculated by the Mean Absolute Percentage Error (MAPE) measurement.

$$
\operatorname{MAPE}(\%)=\frac{1}{n} \sum_{k=1}^{n}\left|\frac{x(k)-\hat{x}(k)}{\hat{x}(k)}\right| * 100
$$

Where, $x(k)$ and $\hat{x}(k)$ are representing actual observation and the simulated (predicted) value obtained through the model, respectively. Therefore, in this study, it is often referred to as MAPE (\%). The Lewis scale (Javed et al., 2020a; Boamah, 2021) was used for interpreting the MAPE values:

$$
\operatorname{MAPE}(\%)=\left\{\begin{array}{cr}
<10 & \text { Highly accurate forecast } \\
10 \sim 20 & \text { Good forecast } \\
20 \sim 50 & \text { Reasonable forecast } \\
>50 & \text { Inaccurate forecast }
\end{array}\right.
$$

\subsection{Relative Growth Rate and Doubling Time Analyses}

The relative growth rate is a measure of normalized growth, which has the advantage of avoiding as much inherent scale difference between contrasting organisms as possible so that the results can be fairly compared (Pommerening \& Muszta, 2015). Doubling time is one of the simplest but quite precise methods of calculating the timeframe by using numbers as growth rates in any context (Todaro \& Smith, 2006). Doubling time can be calculated using the $R G R$ approach, that is why do both of them have a close relationship, and for the application of the relative growth rate $(R G R)$ and the doubling time $\left(D_{t}\right)$ it has been calculated using the following formula Javed and Liu (2018), who proposed the concept of synthetic relative growth rate and synthetic doubling time. They used two parameters $\left(R G R\right.$ and $\left.D_{t}\right)$ model for growth analysis of publications. If $N_{2}$ and $N_{1}$ represent the cumulative number of car productions in the respective years $t_{2}$ and $t_{1}$ then the formulas for relative growth rate and synthetic relative growth rate are given by (Javed \& Liu, 2018),

$$
R G R=\ln \left(N_{2} / N_{1}\right)
$$




$$
R G R_{\text {synthetic }}=\theta \cdot\left(R G R_{\text {actual }}\right)+(1-\theta) \cdot R G R_{\text {forecast }}
$$

The formulas for doubling time and synthetic doubling time are given by

$$
\begin{gathered}
D_{t}=\ln (2 / \mathrm{RGR}) \\
D_{\text {synthetic }}=\theta \cdot\left(D_{\text {actual }}\right)+(1-\theta) \cdot D_{\text {forecast }}
\end{gathered}
$$

where, $\theta$ represents the weighting coefficient, which can generally be valued at 0.5 . $R G R_{\text {actual }}$ represents relative growth rate derived through original data and $R G R_{\text {forecast }}$ represents the relative growth rate derived through simulation of forecast. $D_{\text {actual }}$ represents doubling time derived through original data, $D_{\text {forecast }}$ represents the doubling time derived through simulation of forecast. For further details about relative growth rate and doubling time analysis, Javed and Liu (2018) can be consulted.

\section{Results and discussion}

Ambe and Badenhorst-Weiss (2011) explain that the automotive industry has experienced strong competition on a global scale in highly competitive markets in recent years. Thus, the importance of forecasting to control the growth rate of sales growth in demand for Toyota Avanza in the next few years cannot be ruled out because historically, the industry has operated in a "push" system. In this system, Marketing and Sales uses the best forecast of market demand to communicate these forecasts to the many kinds of need as design, engineering, finance, and manufacturing teams to determine and/or model production volume (Ambe \& Badenhorst-Weiss, 2011).

Data from 2013-2019 was available. Data from 2013 to 2018 was used for forecasting, and data for 2019 was used for out-of-sample testing. Using existing actual data, the simulation values were calculated using EGM $(1,1, \alpha, \theta)$, and the results are presented in Table 2. According to MAPE, the insample accuracy rate of EGM $95.83 \%$ and out-of-sample accuracy was $94.11 \%$ with parameters a $=$ 202972.723 and $\mathrm{b}=0.1380171$ and the results were revealed when following an EGM-based forecasting equation for the Toyota Avanza.

Table 2 shows that the calculation of the cumulative column used actual data from 2013-2018 and the simulation for 2019-2025 and the calculation of Mean RGR and Mean Dt is only used for comparison. RGR itself used cumulative data and Dt is obtained from RGR data that calculated using the Microsoft Excel formula $=\mathrm{LN}(2 /$ (RGR each year data)). Based on the data above, the result shows that MAPE\% for evaluating performance produces MAPE\% (In Sample) from Linear Regression, Exponential Regression, ETS, and EGM showing High Forecast which means the level of accuracy is high. Next, for MAPE\% (Out Sample) from Linear Regression, ETS shows Reasonable forecast, Exponential Regression shows Good forecast, and EGM shows high forecast.

To measure the growth in sales demand for the Toyota Avanza, there are several models have been used such as in Table 2 there are Linear Regression, Exponential Regression, Exponential Triple Smoothing and Even Grey Model. Mean Absolute Percentage Error (MAPE) is used as a test tool to see each model's accuracy. After calculating using MAPE, it turns out that the MAPE\% (In Sample) of the Linear Regression is $6.49 \%$, Exponential Regression is $4.56 \%$, ETS is $5.21 \%$, and EGM is $4.2 \%$. Meanwhile, the MAPE\% (Out Sample) calculation results from Linear Regression is $38.52 \%$, Exponential Regression is $18.13 \%$, ETS is $30.24 \%$, and EGM is (5.9\%). Overall, the statistical models showed worst performance. The results compared through the MAPE test proved that EGM $(1,1, \alpha$, $\theta)$ is the best model for sales forecasting because the MAPE $\%$ values in both in sample and out of sample were $<10$ (high forecast accuracy) as the Lewis scale as well as literature (Quartey-Papafio et al., 2020) asserts that predictions with the MAPE value of less than $10 \%$ are very accurate.

Table 3. Performance evaluation of the forecasting models

\begin{tabular}{|l|c|c|c|c|}
\hline & Linear Regression & Exponential Regression & ETS & EGM (1,1, $\boldsymbol{\alpha}, \boldsymbol{\theta})$ \\
\hline MAPE \% (in sample) & 6.49 & 4.56 & 5.21 & 4.2 \\
\hline MAPE \% (out of sample) & 38.52 & 18.13 & 30.24 & 5.9 \\
\hline
\end{tabular}




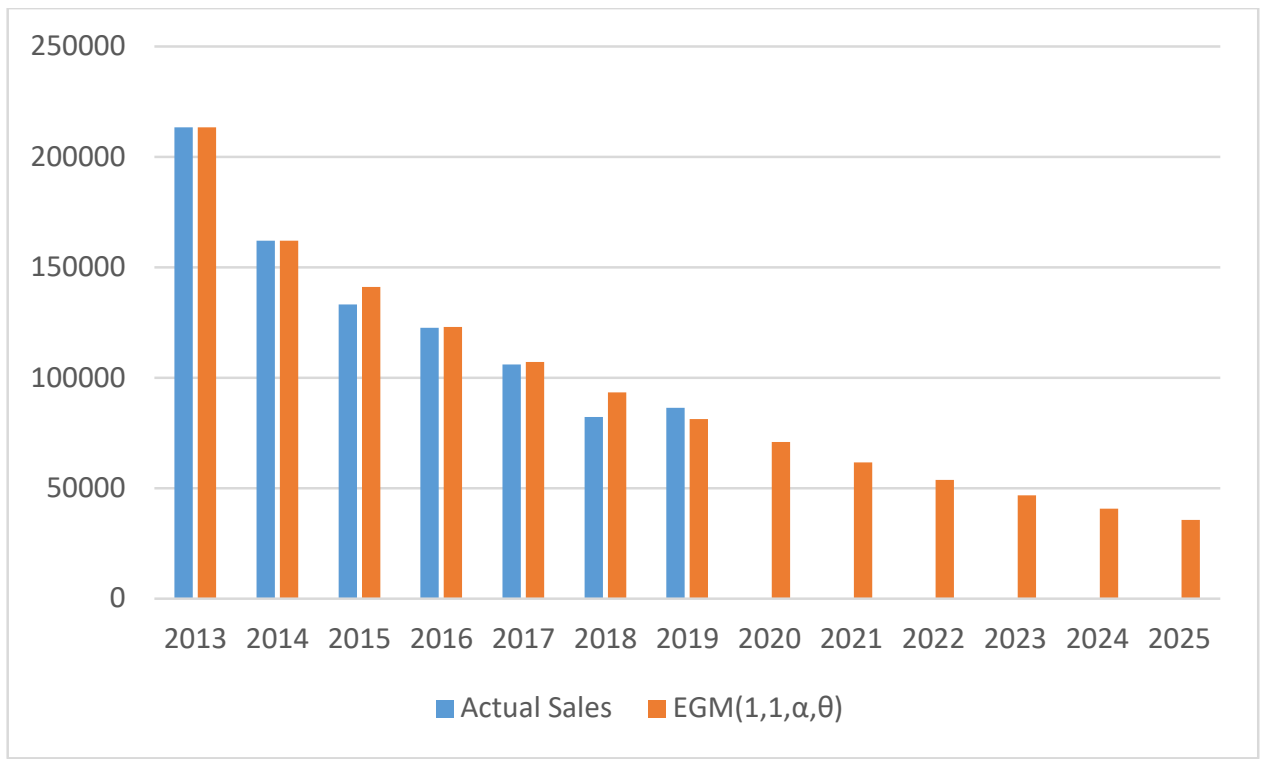

Figure 2. Grey Forecasting of Toyota Avanza Cars in Indonesia

Based on the results shown in Table 3, it can be determined that the appropriate model for the demand of the Toyota Avanza is EGM $(1,1, \alpha, \theta)$ because it has the lowest Mean Absolute percentage (MAPE) level, there are (4.2\%) for MAPE in Sample and (5.9\%) for MAPE out Sample. Thus, its forecast accuracy is at least $94 \%$. According to the Lewis's scale, the forecast is "highly accurate." Based on the forecasts carried out in this study to determine the number of the demand in 2020-2025, the most suitable model is EGM $(1,1, \alpha, \theta)$ with parameters $\mathrm{a}=202972.723, \mathrm{~b}=0.1380171, \theta=$ 0.817147419 and $\alpha=1$.

In the chart above, the red line shows the actual data from 2013 to 2019, the blue lines show the results of linear regression, the purple line shows the result of exponential regression, the yellow line shows the result of exponential triple smoothing and the green line shows the result of the Even gray model. Even though the data in Figure 2 shows many declines, it is not an oddity data because it proves that existing data does not always increase or fluctuate, but there is also another data that is running down but does not indicate a bad decline or bankruptcy. Focusing on the EGM $(1,1, \alpha, \theta)$ that the demand forecast for the Toyota Avanza in Indonesia is experiencing stable and reasonable demand even though the data will gradually decline until 2025 compared to other data. That is why EGM is the best model that can be used for forecasting activities than other statistical models. Even though the result of the demand decreases until 2025, this does not necessarily indicate bankruptcy. In the present, many cars started to be marketed with a variety of models, colors, types and prices offered. Consumers are freer to choose the car they want, and they need now because of the large choices of cars being a sale. From that factor, sales of the Toyota Avanza continue to decline. However, even though it continues to decline, this car still holds the record with the highest sales in Indonesia, as evidenced by the celebration of the highest achievement of Avanza sales in 2019 as it sells 1.8 million units during 16 years of career in Indonesia and there has never been a single car that has been able to touch this achievement in Indonesia's automotive history (CNN, 2020). However, in light of the forecasts, the long-term sustainability of this success is less likely.

\section{Conclusion and recommendations}

The existence of a stable demand makes economic activity good and easy to control. To monitor and control the growth of demand for goods, forecasting should be used to estimate the amount that can be obtained. In this background, the current study was initiated where the Toyota Avanza cars sales in Indonesia were forecasted. When viewed from the actual data, it can be seen from the beginning of the sales that Toyota Avanza has continued to decline since 2014. Forecasting was done using one grey model and three statistical models. All models' accuracy was tested using Mean Absolute Percentage Error. It was found that the even grey forecasting model EGM $(1,1, \alpha, \theta)$ is very accurate when 
compared with the other three methods with an accuracy rate of $95.8 \%$ in-sample and $94.1 \%$ out of sample. The model predicted a decline in the sales of Toyota Avanza till 2025.

The study hopes that this research can be useful for Toyota Avanza Indonesia and allows them to make better plans to improve sales performance. The company should also expand market networks in the domestic and international area and bring new innovations into the car so the Toyota Avanza can develop better in the future and be able to achieve a good increase. Another suggestion is to introduce better alternatives, especially to tap the market of the consumers interested in electric vehicles, which has recently gained widespread attention. Also, in the future, the performance of the Toyota Avanza car's competitors can also be forecasted to get the overall picture of the industry and consumer preferences.

\section{References}

Abu-Eisheh, S. A., \& Mannering, F. L.(2010). Forecasting Automobile Demand for Economies in Transition: A Dynamic Simultaneous-Equation System Approach. Transportation Planning and Technology, 25(4), 311-331. https://doi.org/10.1080/0308106022000019026.

Ambe, I. M., \& Badenhorst-Weiss, J. A. A. (2011). An automotive supply chain model for a demand-driven environment. Journal of Transport and Supply Chain Management, 5(1), 1-22. https://doi.org/10.4102/jtscm.v5i1.18.

Aydemir E. (2020). A New Approach for Interval Grey Numbers: N-th Order Degree of Greyness. Journal of Grey System, 32(2), 89-103.

Berkovec, J. (1985). Forecasting Automobile Demand Using Disaggregate Choice Models. Transportation Research Part B: Methodological, 19B(4), 315-329, 1985. Virginia. 22901 U.S.A.

Boamah, V. (2021). Forecasting the Demand of Oil in Ghana: A Statistical Approach. Management Science and Business Decisions, 1(1), 29-43. https://doi.org/10.52812/msbd.25

Budiman, Y. (2018). Toyota Sales Drop Drastically, This Is The Cause [Penjualan Toyota Turun Drastis, Ini Penyebabnya]. Liputan 6. https://www.liputan6.com/otomotif/read/3580603/penjualan-toyota-turundrastis-ini-penyebabnya. Accessed on 25 November 2020.

Chalil, M. (2017). Toyota Indonesia: PT Toyota Motor Manufacturing Indonesia. Jakarta: PT Ekuator Media Vaganza. pp 5. Available at: https://e-library.toyota.co.id/e-lib/index.php? $\mathrm{p}=$ fstream\&fid=19bid=18252. Accessed on 25 September 2019.

CNN. (2020). Besides Xpander, only Corona can bend Avanza [Selain Xpander, cuma Corona yang bisa tekuk Avanza]. CNN. https://www.cnnindonesia.com/teknologi/20200622023922-384-515829/selain-xpandercuma-corona-yang-bisa-tekuk-avanza.

DetikOto. (2010). History of the Birth of Avanza [Sejarah Kelahiran Avanza]. DetikOto. https://oto.detik.com/berita/d-1351301/sejarah-kelahiran-avanza- . Accessed on 25 September 2020.

Ferrer, A. G., \& Hoyo, J. D., \& Arroyo, S. M. (1997). Univariate Forecasting Comparisons: The Case of the Spanish Automobile Industry. Journal of Forecasting, 16(1), 1-17.

Flood, J. M. (2020). Practitioners Guide to GAAS - Covvering All SASs, SSAEs, SSARSs, and Interpretation. New Jersey: John Wiley and Sons, Inc.

Hakimah, M., Rahmawati, W. M., \& Afandi, A. Y. (2020). Measurement of the Performance of the Exponential Smoothing Type Forecasting Method in its Best Parameters [Pengukuran Kinerja Metode Peramalan Tipe Exponential Smoothing Dalam Parameter Terbaiknya]. Jurnal Ilmiah NERO, 5(1). 44-50. http://dx.doi.org/10.21107/nero.v5i1.150

Hermawan, A. (2005). Business Research: The Quantitative Paradigm [Penelitian Bisnis: Pradigma Kuantitatif]. Jakarta. PT. Gramedia Widiasarana Indonesia. Pp 168.

Hermawan. (2004). Series 9: Hermawan Kartaja Marketing Elements on Brand [Series 9: Elemen Marketing Hermawan Kartaja on Brand]. Bandung. PT. Mizan Pustaka. pp 163.

Iwan, Rahayu, E.I.H. and Yulianto, A. (2018). Mitsubishi Xpander Car Demand Forecasting Analysis with Three Forecasting Methods [Analisis Peramalan Permintaan Mobil Mitshubisi Xpander dengan Tiga Metode Forecasting]. Cakrawala Journal Humaniora Bina Sarana Informatika, 18(2), 249-256. https://doi.org/10.31294/jc.v18i2.4296.

Javed, S. A. and Liu, S. (2018). Predicting the research output/growth of selected countries: application of Even GM $(1,1)$ and NDGM models. Scientometrics, 115, 395-413. https://doi.org/10.1007/s11192-017-2586-5.

Javed, S. A., Ikram, M., Tao, L., \& Liu, S. (2020b). Forecasting key indicators of China's inbound and outbound tourism: optimistic-pessimistic method. Grey Systems: Theory and Applications, 11(2), 265-287. https://doi.org/10.1108/GS-12-2019-0064.

Javed, S. A., Mahmoudi, A., \& Liu, S. (2020a). Grey Absolute Decision Analysis (GADA) method for Multiple Criteria Group Decision Making under Uncertainty. International Journal of Fuz:sy Systems, 22(4), 1073-1090. https://doi.org/10.1007/s40815-020-00827-8 
Javed, S. A., Zhu, B., \& Liu, S. (2020c). Forecast of biofuel production and consumption in top $\mathrm{CO}_{2}$ emitting countries using a novel grey model. Journal of Cleaner Production, 276, 123997. https://doi.org/10.1016/j.jclepro.2020.123997.

Jimmi, A. (2020). Toyota Car Prices Rise, Will Sales Go Down? [Harga Mobil Toyota Naik, Penjualan Bakal Makin Turun?]. DetikOto. https://oto.detik.com/mobil/d-5013037/harga-mobil-toyota-naik-penjualan-bakalmakin-turun. Accessed on 28 September 2020.

Kato, T. (2020). Demand Prediction in the Automobile Industry Independent of Big Data. Annals of Data Science. https://doi.org/10.1007/s40745-020-00278-w.

Lin, C. S., Liou, F. M., \& Huang, C. P. (2011). Grey forecasting model for $\mathrm{CO}_{2}$ emissions: A Taiwan study. Applied Energy, 88(11), 3816-3820. https://doi.org/10.1016/j.apenergy.2011.05.013.

Mahmoudi, A., Deng, X., Javed, S. A., \& Zhang, N. (2020). Sustainable Supplier Selection in Megaprojects through Grey Ordinal Priority Approach. Business Strategy and The Environment. https://doi.org/10.1002/bse.2623

Nishikawa, T., \& Shimizu, S. (1981). Identification On and Forecasting In Management System By Using The GMDH Method In The Case Of The Automobile Industry In Japan. IFAC Control Science and Technology (8th Triennial World Congress) Kyoto, Japan.

Pommerening, A. \& Muszta, A. (2015). Methods of Modelling Relative Growth Rate. Forest Ecosystems, $2,5$. https://doi.org/10.1186/s40663-015-0029-4.

Pracoyo, T. K., \& Pracoyo, A. (2006). Basic Aspects of Microeconomics [Aspek Dasar Ekonomi Mikro]. Jakarta: PT. Gramedia Widiasarana Indonesia.

Prasetya, H., \& Lukiastuti, F. (2009). Operation management [Manajemen Operasi]. Yogyakarta. Media Pressindo.

PT. (2014). Toyota Indonesia: PT Toyota Motor Manufacturing Indonesia. Toyota Indonesia. https://www.toyotaindonesiamanufacturing.co.id/corporate. Accessed on 25 September 2020.

Putri, S. A. (2012). Forecasting Analysis of Mitsubishi Car Demand Type T120 SS at PT Sun Star Motor Solo [Analisis Peramalan Permintaan Mobil Mitshubisi Tipe T120 SS pada PT Sun Star Motor Solo]. Surakarta, Indonesia. https://digilib.uns.ac.id/dokumen/download/28266/NTk3MjE=/Analisis-Peramalan-PermintaanMobil-Mitsubishi-Tipe-Colt-T120-SS-Pada-PT-Sun-Star-Motor-Solo-abstrak.pdf.

Quartey-Papafio, T. K., Javed, S. A. \& Liu, S. (2020). Forecasting cocoa production of six major producers through ARIMA and grey models. Grey Systems: Theory and Application, 11(3), 434-462. https://doi.org/10.1108/GS04-2020-0050

Rahardiansyah, R. (2020). Traffic jams everywhere, how many cars are there in Indonesia? This is the data [Macet di Manamana, Berapa Jumlah Mobil diIndonesia?Ini Datanya]. DetikOto. https://oto.detik.com/mobil/d4870190/macet-di-mana-mana-berapa-jumlah-mobil-di-indonesia-ini-datanya. Accessed on 5 October 2020.

Rayanti, D. (2018). Made in Indonesia Avanza Sells in Which Countries? [Avanza Buatan Indonesia Laku di Negara Mana Aja Sih?]. DetikOto. https://oto.detik.com/mobil/d-4364672/avanza-buatan-indonesia-laku-dinegara-mana-aja-sih. Accessed on 25 November 2020.

Rio. (2019). Commenting on the History of the Toyota Avanza From Time to Time [Mengulas Sejarah Toyota Avanza Dari Masa Ke Masa]. KabarOto. https://kabaroto.com/post/read/mengulas-sejarah-toyota-avanza-dari-masake-masa. Accessed on 25 September 2019.

Riyanto, A. (2005). Invest Carefully. Tips for Buying a Used Car [Cermat Berinvestasi. Kiat Membeli Mobil Bekas]. Tanggerang, Kawan Pustaka.

Rusli, M. (2014). Fun Statistics Management [Pengelolaan Statistik yang Menyenangkan]. Yogyakarta. Graha Ilmu.

Rusov, J., Misita, M., Milanovic, D. D., \& Milanovic, D. L. (2017). Applying Regression Models to Predict Business Result. FME Transactions, 45(1), 198-202. https://doi.org/10.5937/fmet1701198R.

Shahabuddin, S. (2009). Forecasting automobile sales. Management Research News, 32(7), 670 - 682. https://doi.org/10.1108/01409170910965260.

Sikker, D. (2019). Toyota Avanza Consistently Becomes the Favorite Car in Indonesia [Toyota Avanza Konsisten Jadi Mobil Favorit di Indonesia]. OtoExpo. https://otoexpo.com/artikel-baru/toyota-avanza-konsisten-jadi-mobilfavorit-di-indonesia. Accessed on 5 October 2020.

Soerjopranoto. (2017). Avanza Seken Not Glanced Because of Xpander, Toyota Says [Avanza Seken Tak Dilirik Garagara Xpander, Ini Kata Toyota]. https:// sains.kompas.com/read/2017/11/26/120200315/avanza-seken-tak-dilirik-gara-gara-xpander-inikata-toyota. Accessed on 25 September 2020.

Sugiarto, Herlambang, T., Brastoro, Sudjana, R., \& Kelana, S. (2007). Micro Economics "A Comprehensive Study" [Ekonomi MIKRO “Sebuah Kajian Komprehensif”]. Jakarta: PT. Pp 34. Gramedia Pusataka Utama.

Todaro, M. P., \& Smith, S. C. (2006). Economic Development Ninth Edition, Volume 1 [Pembangunan Ekonomi Edisi Ke Sembilan, Jilid 1]. Jakarta, Indonesia: Erlangga.

Wahyudi, S. T. (2017). Economic Statistics: Concepts, Theory and Application [Statistika Ekonomi: Konsep, Teori dan Penerapan]. Malang: UB Press. ISBN: 978-602-432-293-9. 